\title{
Determinants of Bankruptcy Banking after the Global Financial Crisis (GFC): Theoritical Review
}

\author{
Asfahan Amir Ishak and Abdul Mongid \\ Department of Management, STIE Perbanas Surabaya, Surabaya \\ e-mail: asfahanishak@gmail.com
}

\begin{abstract}
The failure of some financial institutions can cause other banks to go bankrupt, and ultimately cause damage to the financial system throughout the world. Bankrupt is a condition in which a company suffers from a lack of funds to run its business. The paper is conceptual and the design of this research is qualitative method based on a theoretical review from many kinds of literature and previous researches related to this concept. There are two basic theories about (1) signaling theory for providing better information and positive signals about the company, as well as negative signals to and (2) the margin pressure theory for measuring about the risk of negative effects from internal or external forces on a company's profitability margins. This study aimed to determine the significant contribution of internal factors such as size, equity to total asset, loan to asset ratio, cost to income ratio, loan loss reserves, and from external factors such as gross domestic product growth, and inflation in predicting bankruptcy bank after the Global Financial Crisis. The researcher believes that the proposition of this study results can be tested empirically mainly in the banking industry.
\end{abstract}

Keywords-Bankruptcy, Financial Crisis, Financial Ratios, Macroeconomics.

\section{INTRODUCTION}

$\mathrm{T}$ HE development of the economic world today is very rapid, this makes competition among companies increasingly strict and competitive, especially in the business sector of banking services. Banking is one of the important sectors in the financial structure of a country. Relatively low banking performance will cause the productive sector to become a shortage of funds, so that it will hamper production, with the delay of the production will be hampered also the economic growth of a country. Rina Fariana (2014) stated that with the strict competition and mistakes in bank management can result in the number of banking services companies are experiencing bankruptcy because they are not able to compete with their competitors. In the Indonesian economy has suffered turmoil and also suffered several crises. The last crisis, the financial crisis, the phenomenon of the global financial crisis in 2008 originated from the occurrence of a financial company's fault in allocating funds in residential credit payments (subprime mortgage defaults) in the United States (US).

The disaster was subsequently struck after a bad credit and paralyzed several major banks, one of which was Lehman Brothers. After the Lehman Brothers bankruptcy, the world's financial markets are experiencing positions at the lowest level. Many major banks are collapse and the fall of other investment banks in the US. However, not only in the United
States but this disaster also bubbles damage the banking system to Europe and Asia and also propagates to the Asian hemisphere, especially countries such as Korea, China, Thailand, Singapore, Japan, Malaysia, including Indonesian.

In the year 2009, there was a slowdown on economic growth in Singapore. The growth rate of 2009 was recorded at- 0.603 , whereas in the previous year the country's economic growth reached 1.788 percent. This slowdown was due to the high level of Singapore's dependence on exports, especially to European and American countries. (http://www.aric.adb.org).

The global financial crisis of 2008 has a major impact on the economy of developed countries in the USA. In overcoming the catastrophic financial crisis and addressing major banks that went bankrupt, the United States Government was forced to conduct a bailout of 700 billion dollars to 1 trillion US dollars. This bailout policy is not only done by the US government, but also by central banks in Europe and Asia. This bailout is also done by the Indonesian state at Bank Century. Century Bank was assessed as a systemic bank. So should be saved, if this systemic bank is left bankrupt, then its impact on the national economy is very large because it carries a domino effect.

The current phenomenon in Indonesia, from the Indonesian deposit guarantor (LPS), reported the liquidation of 71 banks during the years 2005 to 2016 . Of these, there are 1 public bank and 70 of the People's creditors (BPR) are liquidated. The banks are liquidated due to the average capital adequacy ratio (CAR) of the liquidated banks reaching minus 209.79 percent of the bank. That is, the bank is in a very deadly condition. Such phenomena should be aware of by any companies if such conditions occur again should soon have control of both the internal and external companies. If there is no control then there will be very many companies especially banking services that are experiencing financia difficulties and end with a failure or bankruptcy of the bank.

Bankruptcy can be seen from the financial statements. By analyzing the financial statements, we can know the financial position and the results that the company has achieved. At the health level of the company is very important for the company to be able to improve the efficiency in running its business, so it is more opportunities in obtaining profits that can ultimately avoid the possibility of the company Experiencing bankruptcy conditions.

Bankruptcy predictions can be proved by using financial ratios. Financial ratios can be used as a failure prediction tool for a company. The number of bankruptcy prediction models is an act of anticipation and also as an early warning system or Early Warning Systems (EWS) to predict potential 
The $1^{\text {st }}$ International Conference on Business and Engineering Management (IConBEM)

February $1^{\text {st }} 2020$, Institut Teknologi Sepuluh Nopember, Surabaya, Indonesia

problems that occur in a company can even improve the conditions before and may have suffered a condition of crisis or failure. In the United States (US), the company's bankruptcy phenomenon has become an intensive object of research. The tradition of this study was initiated by Braver (1966) and was continued by Altman (1986), Altman et al (1977) and Gilbert et al (1990).

Bankruptcy can globally be defined as the success of the company is running the company's operations to generate profit [1]. According to Amilia in Syinta (2018:14) referred to as bankruptcy is an event of failure or inadequacy experienced by the company in fulfilling the obligation to the debtor because the company is experiencing inadequate funds to The goal of achieving the expected profit is not fulfilled. Wulandari (2018) stated before the bankruptcy condition suffered by the company, one of which is the occurrence of financial performance decline.

In this research, the author attempted to conduct research covering the bankruptcy or failure of the banking services company namely by predicting the bankruptcy of banking companies post the global financial crisis that was influenced by several deciding factors. In this study using seven free variables used as determinants or predictions of bankruptcy, namely, bank size, Loan to Asset Ratio (LAR), Equity to Total Asset (ETA), Loan Loss Reserves (LLR), Cost Income Ratio (CIR) inflation and Gross Domestic Product (GDP) Growth. The reason for choosing these seven variables is because in some early studies the authors referred to this study, using several variables with various reasons and findings.

The author also researches the sector of banking services companies because the banking sector contributes importantly to improving the community's living standards and the economic growth of a country. The services provided by the banking sector have made it easier for the public to conduct financial transactions. We can see that the banking companies are very important to the world economy because if the company's banking performance, efficiency, and all activities are weakened it will cause the economic crisis and if there is an economic crisis then Will cause other companies to experience financial difficulties and lead to failure or bankruptcy.

In this study wanted to find out if there was a significant or insignificant influence on bankruptcy conditions in banking companies post the global financial crisis. The purpose of this research is to analyze, determine, and see the extent of bankruptcy in banking companies after the global financial crisis as well as many gaps from previous research outcomes.

\section{THEORETICAL REVIEW}

\section{A. Signalling Theory}

Signal theory describes that the company gives better information and positive signals about the company, as well as negative signals to users or users of financial statements such as potential investors. According to Jogiyanto (2000: 392 ), stated the information provided by the company contained announcements expected by market share.

According to Brigham and Houston, the signal or signal is an action taken by the company to give instructions to investors about how management views the company's prospects. This signal is in the form of information about what has been done by management to realize the owner's wishes. Information released by the company is important because it affects the investment decisions of parties outside the company. This information is important for investors and business people because the information essentially presents information, notes or pictures, both for past, present and future conditions for the survival of the company and how it affects the company.

\section{B. Agency Theory}

The agency theory describes the relationship that includes the contract or licensing between one side, the shareholders as principal and the other side management as an agent. According to Irham Fahmi (2014: 19), the agency theory is a condition that occurs in a company where the management as executor and capital owners as principal that builds cooperation contains the agreement that Management should work to provide maximum satisfaction such as making a high profit for the capital owner.

In this theory of agency, the relationship between a principal and an agent can lead to an information imbalance condition or the information asymmetry. Asymmetry of information is the information obtained between the agent and the principal are not balanced, the agent has more information about the company than the principal. The existence of this information asymmetry is due to the people who want to maximize their self-interest. Information asymmetry can also create an agency to hide some information that is not known by the principal. The agents have full information and on the other hand, have the advantage of shareholder power or discretionary power. Therefore, it can be concluded that both sides have a personal interest in any decision specified [2].

\section{Margin Pressure Theory}

Margin pressure is the result of negative changes in margin ratios resulting in decreased unit profitability per revenue. Margin analysis is primarily used to understand how profitable unit sales are at different points on the income statement in comparison to total revenue. In general, anything that makes a company's costs or revenues change will usually cause a change in the margin. Margin pressure is perceived as any cost or revenue change that could lower a margin calculation, ultimately resulting in lower profitability.

Margin pressure is a type of risk that companies seek to mitigate or avoid. It can be related to macroeconomic events such as an economy-wide increase in costs or comprehensive changes in regulations. In banks there can be several other effects for companies when seeking to manage margin pressure, if a company faces increased regulation, or if a company experiences internal production problems or unexpected labor problems then it can pressure margins.

Responding adequately to the challenge of maintaining profit margins requires a deft combination of strategic and operational measures since the two are inextricably linked in the performance management cycle. For example, such as entering new markets and the develompment of new products can have a direct bearing on projected margin performance captured in business plans and forecast. Traditional banks face increasing competition from digital-only players, leading to further pressure on net interest margins.

Margin pressure is the risk of negative effects from internal or external forces on a company's profitability margins. 
The $1^{\text {st }}$ International Conference on Business and Engineering Management (IConBEM)

February $1^{\text {st }} 2020$, Institut Teknologi Sepuluh Nopember, Surabaya, Indonesia

Margin pressure is perceived as any cost or revenue change that could lower a margin calculation, ultimately resulting in lower profitability. Margin is calculated to identify the profitability of a unit of sales when adjusting for different costs. Gross, operating, and net margin are the three main margin calculations most analysts focus on but other types of margin calculations can also exist. In all margin calculations, a unit of sales is adjusted for certain costs and divided by total revenue.

So, profit margins are under pressure from a combination of geo-political change, unprecedented economic volatility and structural changes such ad the impact of the internet on trading methods. In response to the more testing conditions, businesses have "tightened their belts" and sought to reduce costs. But, with an inability to control prices and costs already cut to the bone there are seemingly few places to turn to for improved profitability.

In banks, credit growth across the banking system is expected to be modest amid slow economic growth environment. Despite the slower credit growth and weakening asset quality likely to apply pressure on profitability, analysts expect banks to benefit from strong capitalisation level, stable funding and healthy liquidity. Banks that lent more to micro-sized and small businesses, usually at lower interest rates but at higher credit risk, appeared to have faced more margin pressure. The margin pressure theory in this study supports the variables profitability, macroeconomic and quality assets.

\section{Bankruptcy}

According to Rina Fariana (2014), bankruptcy is a failure of a company in carrying out company operations to generate profit or severe liquidity so that it is unable to run operations properly. In general, bankruptcy is a failure of a company in carrying out its operations to achieve predetermined goals. However, the reality faced by a company does not always go according to plan. In certain conditions, companies will experience financial difficulties such as liquidity difficulties. If minor difficulties such as liquidity are not handled properly, then actual difficulties will develop into major difficulties and will experience bankruptcy.

Bankruptcy will quickly occur in companies that are in countries experiencing an economic crisis, because this condition will trigger more rapid bankruptcy of companies to occur, especially in banking service companies. The failure of a bank not only causes problems for individual banks but will spread and have a domino effect in other industries because banks have the role of intermediation. According to Hanafi in Abdul Kadim et al (2018), the condition of bankruptcy can be seen from the flow approach and stock approach. By using the stock approach, a company can be declared bankrupt if total liabilities exceed total assets. By using the flow approach, a company will go bankrupt if it cannot generate sufficient cash flow.

\section{E. Risk Management}

Risk management is an approach used to manage the uncertainty associated with short-term and long-term threats. Risk management in the company is needed to avoid the various risks that are not expected by the company. Savings from the public will be used to finance bank operations and to obtain the desired income. The greater the desired income the greater the risk that will be faced, according to the "HighRisk High Return" theory.

In banking, there are many risks to be faced, because everything in the operation of a bank must have various types of risks. In terms of investment, lending, or decision making, even other events will affect the flow of bank funds. In managing their assets, banks do various methods to get good results for the bank's reputation.

Each allocation of assets is a plan that must be considered because one of them is related to the level of liquidity and profitability. If the disbursed funds are not liquid, then management is deemed unable to properly manage risk management and does not apply the precautionary principle so that there is a failure to pay. According to Abdullah et al (2015) banks who are riskier will set more reserves to meet loan losses.

\section{F. Bankruptcy Measurement}

In banking, we must pay attention to the profitability side. Profitability shows the ability of banks to earn profits effectively and efficiently, the magnitude of profitability can show most of the bank's performance can be said to be good because banks can operate effectively and banks have the opportunity to expand their business. A bank needs to maintain the stability of its profitability to fulfill various obligations to shareholders and attract investors to invest capital, and to increase the loyalty and trust of the public to save their funds in the bank. The profitability ratio used in this study to measure the probability of bankruptcy is Return on Assets (ROA), a function of the ROA ratio which is to measure the level of effectiveness of a company in generating profits by utilizing the effectiveness of the company through the operation of assets owned by the company.

According to Khrawish (2011), Return on Assets (ROA) is the main ratio that shows bank profitability. Bank Indonesia, as the supervisor of banking, prioritizes the profitability of a bank which is measured using assets whose funds are obtained from public deposits (Dahlan Siamat, 2005: 74). Every company would want to achieve maximum profits. In other words, ROA shows how efficiently the company's resources are used to generate revenue. If a bank with a low ROA level is caused by the profit generated by the bank in a negative condition or the bank suffers a loss, this shows that the ability of the whole invested capital has not been able to generate profits. This will result in a banking crisis, if this condition is not resolved immediately it will lead to bankruptcy.

Conversely, if the level of ROA is high then the company has good efficiency because of the greater the level of profits achieved so that the possibility for a crisis and even bankruptcy the smaller. High ROA results also indicate the company's financial performance is getting better because the rate of return will be even greater. ROA can also be used to measure the financial performance of multinational companies when viewed from the perspective of profitability and investment opportunities [3].

The second measurement of bankruptcy is using bank equity. Equity is the amount of capital that describes a person's ownership rights over assets in a company. From this equity, it can be seen how much someone's ownership of a company. Capital is one of the specific factors of a bank that influences the level of profitability of the bank. Capital is the 
The $1^{\text {st }}$ International Conference on Business and Engineering Management (IConBEM)

February $1^{\text {st }} 2020$, Institut Teknologi Sepuluh Nopember, Surabaya, Indonesia

number of funds available to support the bank's business and act as a buffer in the event of a risky situation [4]. Capital can come from internal or external companies.

Capital or internal funding can be in the form of retained earnings and also depreciation. While capital obtained from externally comes from creditors, debt holders, and company owners. In the implementation and development of business, the role of capital is needed, in general, there are two basic forms of financing in companies. First, own capital from internal sources and debt from external sources. Internal sources, namely funds from within the company are the fulfillment of capital needs taken from the funds generated by the company itself. In this case, the internal source is often referred to as the main source to finance investment in fixed assets or capital expenditure.

\section{G. Cause of Bankruptcy}

According to Jauch and Glueck in Adnan in Abdul Kadim and Sunardi N. (2018), the causes of bankruptcy include:

1) General Factor

a. Economic Sector

There are symptoms of inflation and deflation in the price of goods and services, financial policy, devaluation or revaluation and interest rates about foreign currencies and balance of payments, surpluses, and deficits in relations with foreign trade.

b. Social Sector

There are changes in people's lifestyles that affect demand for products and services. Another social factor is the chaos that occurs in the community.

c. Technology

The use of technology can cause the costs borne by the company to swell, especially for maintenance and care.

d. Government Sector

The influence of the government sector stems from government policies on the removal of subsidies on industrial companies, the imposition of export and import tariffs, new law policies for banks or other workers.

2) External Factor

a. Consumer Factor

Companies must be able to identify the nature of consumers because to avoid losing consumers and to create opportunities to find new customers.

b. The Creditor Factor

Its strength lies in lending and obtaining a repayment period that depends on the creditor's confidence in a company's liquidity.

c. Competitor Factor

This factor is a matter that must be considered because it involves differences in the provision of services to consumers, the company also should not forget its competitors because if the competitor's products are more accepted by the community the company will lose consumers and reduce the income received.

3) Internal Factor

a. Too much credit given to customers that will cause arrears in payment until finally unable to pay.

b. Inefficient management caused by a lack of ability, experience, skills, and attitude of initiative from management. c. Abuse of authority and fraud which is often done by employees, even top managers even very detrimental especially those related to corporate finance.

\section{H. Financial ratio}

In preparing financial statements that contain figures which are the results of the company's performance in a certain period. These figures cannot give a certain meaning if not formulated and applied using financial statement analysis, in this financial statement analysis using financial ratio analysis techniques. One ratio analysis that researchers use is Company Size, Loan to Asset ratio (LAR), Equity to Total Assets (ETA), and Cost Income Ratio (CIR).

Loan to Asset ratio (LAR) is one of the liquidity ratios, this ratio is used to measure the ability of banks to meet credit demand using the total assets owned by the bank. The amount of the Loan to Asset ratio (LAR) will cause a liquidity problem. According to Idroes Ferry N (2011) that there is a theory of "high risk, high return", this theory shows that efforts to obtain greater income by shooting proportions in activities can lead to greater risk.

Equity to Total Assets (ETA) is one of the ratios from the aspect of capital by measuring the number of assets financed by investment owners by comparing the company's capital with total assets. Companies with higher equity ratios show investors and new creditors who are trusted by the company and are willing to finance it with their investments. According to Chen-Min Hsu and Wan-Chun Liu (2019), the ETA ratio has a significant effect on predicting bankruptcy during a financial crisis, while according to Alexandre Momparler, Pedro Carmona, and Francisco Climent (2016) the results of his research show that the ETA ratio cannot help predict and prevent bankruptcy in the banking sector.

A company must pay attention to company size. The size of the company describes how much the total assets owned by a company. The size of the company as a determinant of the company can pay off obligations or not. If the total assets in the company are increasing, of course, the value of the asset is greater, then the company will pay off its short-term obligations and for the future.

Cost Income Ratio (CIR) is a ratio that is important and a lot of attention in bank analysis. According to Veithzal et al (2013: 482), this ratio is comparing the bank's operational costs with operational income in measuring the level of efficiency and the ability of banks to carry out their operations. This assessment is based on bank profitability which can be seen from the ability of banks to generate a profit [5].

Loan Loss Reserves are estimates of the number of bank loss exposures to cover bad debts that are not collectible. Loan loss provisions are the costs required to adjust loan loss reserves. Loan loss reserves are also useful information for analysts and investors because they indicate the bank's feelings about how stable the loan base is. However, banks differ in terms of deciding how many loans to write off and when which sometimes makes comparisons between banks difficult. The loan loss reserve is revised every three months. An increase in balance is called a loan loss provision. A decrease in balance is called a net charge-off. 
The $1^{\text {st }}$ International Conference on Business and Engineering Management (IConBEM)

February $1^{\text {st }} 2020$, Institut Teknologi Sepuluh Nopember, Surabaya, Indonesia

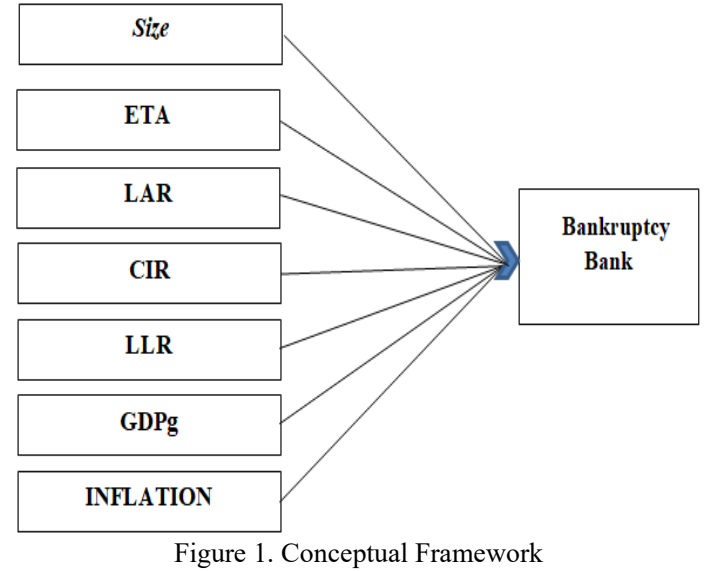

Excessive Loan Loss Reserves (after bad loans are written off) increase the lending side's balance sheet assets. It can be concluded that when the credit quality is bad or entering into a non-performing loan and many debtors cannot repay their debts and the banks increase the loan loss reserve. In this condition, banks may lack the capital to distribute loans, which in turn will cause difficulties in fulfilling loan requests. In the research of Chen-Min Hsu and Wan-Chun Liu (2019), the results show that Loan loss reserves (LLR) have a significant effect on bankruptcy or bank failures because of the weaker quality of assets owned by a bank will lead to a higher risk of failure.

\section{Macroeconomic}

Macroeconomics explains economic changes that can affect society, companies, and markets. According to Robert S. Pindyck and Daniel L. Rubinfeld (2009), macroeconomics is economics that deals with economic aggregate variables such as the average level of national production growth, unemployment, interest rates, and inflation. In this study, the macroeconomic variables used are the Gross Domestic Product (GDP) Growth and Inflation.Gross Domestic Product (GDP) Growth is one indicator used as a measure in assessing the economy of a country. GDPg is the final value of all manufacturing and service sectors, both at current prices and at constant prices [6].

Inflation is an increase in the price of goods and services, which occurs as a result of greater demand compared to the supply of goods, in other words too much money chasing too little money [7]. Inflation occurs because of the macroeconomic uncertainty of a country, this uncertainty will result in people using their funds for consumption.

\section{METHOD}

This paper is conceptual and qualitative in nature. It originated from various previous studies related to the bankruptcy of banks. some previous studies explain the influence of financial and macroeconomic ratios used in this study with the bankruptcy of banks.

\section{RESULT AND DISCUSSION}

Based on the theoretical foundation and previous research and the problems that have been raised, as a basis for formulating a hypothesis, a framework of thought can be presented in the model in the Figure 1.

\section{A. Effect of Size in Predicting Bankruptcy of Banks.}

The size of the company seen from the total assets, if the company has large total assets, it can cover liabilities (debt). The company always expects greater total assets to be able to pay short-term or future obligations if the obligations are not paid, they will accumulate and have an impact on bankruptcy. So, the size of this company is very influential if the total assets are large, it will anticipate bankruptcy conditions. Previous studies have found that size can predict the risk of bank failure [8]. In contrast to research from Loredana Cultera and Xavier Bredart (2016) states that size is not significant to business failure.

\section{B. Effect of Equity to Total Assets in Predicting Bankruptcy of Banks.}

Equity to total assets (ETA) is one of the ratios used to measure and show the attachment of capital owners to the business continuity of the bank concerned. Each bank must pay attention to the position of this ETA ratio because this ratio can show the percentage of investment in total assets that have been used with funds originating from their capital. This ratio also reflects the importance of loan funds and own capital and the level of security for creditors.

The higher the ETA ratio can reduce the possibility of bankruptcy occurring because it shows that the lower the portion of the debt that will later reduce the possibility of bankruptcy. The greater the portion of the debt in a bank shows that the greater the bank's obligation to pay the debt in the future. The number of liabilities that are too large will cause the bank to fall into a state of bankruptcy because the bank is unable to fulfill its obligations at maturity. Previous research that measured capital using ETA found that this ratio cannot be used to predict the bankruptcy of banks [9]. In contrast to the research of Chen-Min Hsu and Wan-Chun Liu (2019) found that the ETA ratio can be significantly used to predict bankruptcy.

\section{Effect of Loan to Assets Ratio in Predicting Bankruptcy of Banks.}

Using the Loan to Assets (LAR) ratio can show a bank's ability to meet credit demand using the total assets owned by the bank. The LAR ratio also shows a comparison of how much credit a bank gives compared to the number of total bank assets. The higher this ratio, the smaller the problem banks will be. Conversely, if this ratio is low then the possibility of problem banks is even greater. Previous studies have explained that LAR has a significant effect on problematic conditions in banks [10].

\section{Effect of Cost Income Ratio in Predicting Bankruptcy of Banks.}

Banks must pay attention to various costs in conducting activities in banking. This ratio takes into account the measurement of efficiency at the bank. Cost efficiency is defined as the ratio between the minimum costs at which a company can produce a certain amount of production, with the actual costs that have been incurred. Banks that operate with a low level of efficiency have costs that tend to be higher, caused by inadequate credit and controlling operational cost-efficiency.

When this ratio is high, it shows that costs are increasing at a higher rate than the income earned. the inefficiency of 
The $1^{\text {st }}$ International Conference on Business and Engineering Management (IConBEM)

February $1^{\text {st }} 2020$, Institut Teknologi Sepuluh Nopember, Surabaya, Indonesia

production, the company is included as a failure. If the cost efficiency is high then the company can go bankrupt due to the company's inability to utilize the costs in creating revenue. Conversely, if a bank with a low CIR ratio, the bank's efficiency is good and reduces the probability of bankruptcy because it can generate greater income than spending various costs and good quality of the bank's management.

If the cost efficiency is high then the company can go bankrupt due to the company's inability to utilize the costs in creating revenue. Previous research measuring efficiency using the CIR ratio found that this ratio had a significant positive impact in predicting the likelihood of bankruptcy [11]. Meanwhile, according to Calvin W. H. Cheong et al (2019) the CIR ratio cannot be used to predict bankruptcy of banks, or with results that are not statistically significant.

\section{E. Effect of Loan Loss Reserves in Predicting Bankruptcy of Banks.}

In a bank for the quality of carrying out its functions, it can be seen from the ability to manage funds to minimize the risk of losses that can occur such as credit or financing risks, because if these risks occur the bank may potentially fail. The function of establishing Loan Loss Reserves is to avoid potential business failures that may be experienced by banks if the debtor is unable to meet the obligations in paying the loan.

The formation of reserves with an amount that is too large indicates that the bank is not competent in carrying out risk management and decreasing the level of profitability in line with a large number of funds that must be reserved. Things like this can make banks in an unhealthy condition that will lead to bankruptcy.

Banks that have a greater risk, especially on the quality of their credit, must reserve more loan losses because if they do not reserve it will experience difficulties when the debtor defaults.

If the bank has a loan loss of less than $5 \%$, it will likely experience difficulties and in the end, the bank will experience an unhealthy condition, but on the other hand, if a bank that has a loan reserve above $5 \%$ means that the bank has a lot of Non-Performing Loans, this condition is very bad. good for the health of banks so that if left unchecked can lead to bankruptcy due to the number of debtors who default and the low level of loan loss reserves at the bank. The existence of a high loan loss reserve at a bank indicates that the effectiveness of internal control is an important factor of the estimated loan loss [12].

\section{F. Effect of Gross Domestic Product growth in Predicting Bankruptcy of Banks.}

Apart from the financial ratio aspect, banks must pay attention in terms of macroeconomics. Gross Domestic Product (GDP) growth is one indicator used as a measure in assessing a country's economy and GDPg has a broad influence on the country's economy. The higher GDPg, the better for the economy with the contribution of household consumption expenditure has the largest portion in contributing to GDPg, the fertile economic growth and the possibility of bankruptcy is smaller. Conversely, if GDPg is low then the possibility of bankruptcy is even greater, due to a decrease in income, and low employment opportunities.
Previous research found that GDPg did not affect the bankruptcy of banks [13]. Whereas in the research of Laura Chiaramonte et al (2016) shows that GDPg has a significant positive impact in predicting bank failures.

\section{G. Effect of Inflation in Predicting Bankruptcy of Banks.}

Banks must pay attention to the rate of inflation because inflation has an important role in a country's economy. Inflation will have a wide impact on economic growth, external balance, competitiveness, interest rates, and income distribution. The higher inflation rate will cause the bank's condition to be more fragile because people's income is used for consumption rather than saving money in the bank. This causes banks to lack savings because customers tend to make withdrawals, causing bank financial conditions to be bad. Previous research shows that inflation has no significant effect in determining the banking crisis [14]. Whereas in the research of Laura Chiaramonte et al (2016) it shows that inflation has a significant negative impact on the probability of banking failure.

\section{H. Limitations}

The lack of papers on bankruptcy makes the depth of discussion rather limited.

\section{Recommendation}

The results of the conceptual framework in this study can be used and tested empirically for further research related to bankruptcy, especially in the banking industry sector.

\section{REFERENCES}

[1] V. Eliu, "Pengaruh financial leverage dan firm growth terhadap financial distress," Finesta, vol. 2, no. 2, pp. 6-11, 2014

[2] I. Fahmi, Manajemen Kuangan dan Pasar Modal. Jakarta, Indonesia: Mitra Wacana Media, 2014.

[3] S. Husnan, Manajemen Kuangan-Teori dan Penerapan. Yogyakarta: BPFE, 1998

[4] P. P. Athanasoglou, S. N. Brissimis, and M. D. Delis, "Bank-specific, industry-specific and macroeconomic determinants of bank profitability," J. Int. Financ. Mark. Institutions Money, vol. 18, no. 2 , pp. 121-136, 2008

[5] K. Kasmir, Analisis Laporan Keuangan. Jakarta, Indonesia: Raja Grafindo Persada, 2015.

[6] N. G. Mankiw, Principles of Macroeconomics. Mason, Ohio Thomson South-Western, 2004

[7] S. Sukirno, Makro Ekonomi Teori Pengantar. Jakarta, Indonesia: PT Raja Grafindo Persada, 2004.

[8] L. Cultrera and X. Brédart, "Bankruptcy prediction: The case of Belgian SMEs," Rev. Account. Financ., vol. 15, no. 1, pp. 101-119, 2016.

[9] A. Momparler, P. Carmona, and F. Climent, "Banking failure prediction: a boosting classification tree approach," Rev. Esp. Financ y Contab., vol. 45, no. 1, pp. 63-91, 2016.

[10] R. Fahriana, "Prediksi kondisi bermasalah berdasarkan analisis rasio camel meggunakan pendekatan logistic regression pada lembaga perbankan yang go publik," Maj. Ekon. Telaah Manjemen, Akuntansi, dan Bisnis, vol. XVIII, no. 1, pp. 116-130, 2014.

[11] L. Chiaramonte, F. H. Liu, F. Poli, and M. Zhou, "How accurately can Z-score predict bank failure?," Financ. Mark. Institutions Instruments, vol. 25, no. 5, pp. 333-360, 2016.

[12] M. Cho and K. H. Chung, "The effect of commercial banks' internal control weaknesses on loan loss reserves and provisions," J. Contemp. Account. Econ., vol. 12, no. 1, pp. 61-72, 2016.

[13] D. Hamida, N. Ahmar, and S. Djaddang, "Determinan prediksi krisis perbankan berbasis banking sector fragility index," JIAFE (Jurnal Ilm. Akunt. Fak. Ekon., vol. 3, no. 2, pp. 1-16, 2018

[14] N. Othman, M. Abdul-Majid, and A. Abdul-Rahman, "Determinants of banking crises in ASEAN countries," J. Int. Commer. Econ. Policy, vol. 9 , no. 3,2018 